\title{
Ligneous Species Tolerance in Acid Sulphated and Saline Soils of Sine Saloum: Case of Rural Community of Djilass and Loul Secene
}

\author{
Antoine Sambou \\ School of Environmental Studies, China University of Geosciences (Wuhan), 430074, Wuhan, China \\ E-mail: tonysambouegos@yahoo.fr \\ Babou NDOUR \\ Senegalese Institute of Agronomic Research (SIAR)/ National Center of Agronomic Research \\ (NCAR) Bp 53- Bambey-Senegal \\ Shenggao Cheng \\ School of Environmental Studies, China University of Geosciences (Wuhan), 430074, Wuhan, China \\ E-mail: chengsg@cug.edu.cn \\ Elie SENGHOR \\ Ingénieur des Travaux des Eaux et Forêts
}

Agent de l'Etat au Ministère de l'Environnement, de la Protection de la Nature, des Bassins de Rétention et des Lacs Artificiels, Direction des Eaux, Forêts, Chasses et de la Conservation des Sols -Senegal

E-mail: senghorelie@yahoo.fr

\begin{abstract}
Salinity and acidity of soils remain one of the world's oldest and the most serious environmental problem, which substantially hampers crop and ecosystem productivity in arid and semi arid areas. This problem has been addressed by expensive and energy depleting soil reclamation measures. In this study, we tested salinity and acidity tolerances of ten ligneous species. This Investigation was undertaken in the scope of my thesis in the project' agrosylvopastoral economic development of saline and acid sulphated soils in Sine-Saloum by ligneous regeneration'. It was done in the rural communities of Djilass and Loul Secene, sub-prefecture of Fimela, Department and province of Fatick.

The study consisted to evaluate the ligneous vegetation tolerance in the experimental plot of the project.

The adopted experimental method is a factorial with two factors (type of plot and Species). The first factor (type of plot) has three levels (Pure plot, herbaceous plot and shrubby plot) and the second factor (species) has ten levels (Acacia seyal, Acacia tortilis, Acacia nilotica, Acacia Senegal, Acacia ampliceps, Melaleuca acacioides, Melaleuca viriflora, Prosopis juliflora, Prosopis cineraria and Casuarina equisetifolia). The sites (villages) are taken as repetitions. Three plots are considered in Djilass and Ndoff-Faoye. Each kind of species is planted in $625 \mathrm{~m}^{2}$ space and the distance between species is $5 \mathrm{~m} * 5 \mathrm{~m}$. The holes adopted for plantation are $40 \mathrm{~cm} * 40 \mathrm{~cm} * 40 \mathrm{~cm}$. The measured parameters are survival rate, height and stem diameter of species. The plots characterization permits to know the salinity and the acidity of each plot. All the plots are salted and acid but the salinity and acidity degree vary according to the type of plot. The salinity levels range between EC $1.38 \mathrm{~ms} / \mathrm{cm}$ and EC $14.02 \mathrm{~ms} / \mathrm{cm}$ and the ph levels vary from 4.74 to 5.9. The species tolerance depends not only on the salinity and acidity degree but also on the species type. These findings indicate that some species tolerate the salinity and acidity and others are sensitive.
\end{abstract}

Keywords: Salinity, Acidity, Species, Tolerance, Survival, Growth

\section{Introduction}

Nowadays, $\sim 20 \%$ of the world's cultivated land and nearly half of all irrigated lands are affected by salinity. High concentrations of salts cause ion imbalance and hyper osmotic stress in plants. As a consequence of these primary effects, secondary stresses such as oxidative damage often occurs [Rhoades, J.D. and Love day, J. 1990].Salinity of soils and groundwater is a serious soil degradation problem, which is growing steadily in many parts of the world, including Senegal. It is a multidimensional problem in several countries and has wide macro and micro socio-economic implication. It occurs mainly but not exclusively, in arid and semi-arid regions, low lying areas and river valley [Akhtar et al, 2002].

In Senegal and Gambia, the salted soils take over around one million $(1,000,000)$ ha. In Sine-Saloum alone, over 230, 000 ha which cover more than one quarter of its total surface area [Marius, C., 1985] [Massibot, J.A. and Carles L., 1946].

Not adapted to the agriculture requirements, these soils, almost sterile, are characterized by a very important content of salt, affecting them on a more or less great thickness. The stressing of the soils salinity in this agro-ecological zone is caused by the fact that the rivers Sine and Saloum are not fed any more out of fresh water. The salinity and the acidification therefore reach 60 to $80 \%$ of these basins soils [Sadio, S., 1991]. 
In Fimela district where the processes of salinisation are accentuated, $50 \%$ of the surface area are affected by the phenomenon which becomes extremely worrying [Ndour B. And Sarr A., 1994].

Saline and acid sulphated soils are grounds of which pedogenesis is dominated by the processes of iron oxydoreduction which has been caused, with a clogging, by the presence of a temporary water table and by the ponding of rains [Diop, M., 2001].

A saline and acid sulphated soil may be liable to flooding by the tides of sharp water, located at the behind of the mangrove swamp where the high salinity of the soil prohibits any vegetation (pure plot) or tolerates a characteristic type of vegetation dominated by Borreria verticillata associated or not with shrubs such as Combretum glutinosum, Balanites aegyptiaca, Tamarix senegalensis (herbaceous or shrubby plot). The saline and acid sulphated soils are characterized by a rare or exceptional inundation, an intense evaporation, a prolonged draining of the superficial horizon supporting the concentration of the salts tripped up by capillarity and clay, therefore more impermeable. The salted water table, generally near to surface, concentrates on the plot by evaporation and prolonged drying of the superficial horizon, leads to the formation of a crust or a fitted carpet which prohibits any vegetation. These soils require necessarily a human intervention for their restoration and development. The plots herbaceous and shrubby are characterized by a superficial desalination of profile which allows the installation of specific vegetation. The afforestation of the saline soils can initially allow an agro-sylvo-pastoral valorization and a fight against the phenomenon of degradation of by sulphating and acidification.

Salinity and the acidification involve a strong chemical degradation of the soils and compromise the possibilities of development because of the toxicity caused by the excessive accumulation of salts and acid products [Sadio, S., 1986]. So if measures going in the direction of the fight against this phenomenon are not taken, a very large part of cultivable surface of Sine and Saloum will be transformed into saline soils, thus endangering the population survival.

The actions of research and development suggested in this present study have a particular economic and ecological importance. They fall under the identification of woody species likely to tolerate the saline and acid sulphated soils.

\section{Material and methods}

\subsection{Study Area}

In this study, data were collected from six research fields located in the villages of Djilass and Ndoffe-Faoye, in the rural communities of Djilass and Loul Secene, district of the fimela, Fatick province in Senegal.

The soils found at these sites are characterized as tropical ferrugnous and salted soils. Fatick Province has a climate caracterised by the alternation of two seasons: dry season which is spread over eight to nine months and rain season. The temperature fluctuates between $24^{\circ} \mathrm{C}$ (in January) and $39^{\circ} \mathrm{C}$ (in May).

Insert map 1

The geographical coordinates of the experimental pieces were taken in order to carry out a chart of the plots situation compared to the villages in the respective rural communities. With the help of GPS ${ }^{1^{*}}$ and ArcGIS software; we located and had the geographical coordinates of all the plots.

site of Djilass:

This site contains three experimental plots or morphopedologic units (pure plot, herbaceous plot and shrubby plot).

Pure plot

It is located at the North-East about some kilometers from Djilass, at latitude $1415^{\prime} .064 \mathrm{~N}$ and longitude $16^{\circ}$ 37 '.344W.

Herbaceous plot

Located west of Djilass, it is in the latitude $14^{\circ} 14.553 \mathrm{~N}$ and longitude $16^{\circ} 38.623 \mathrm{~W}$.

Shrubby plot

It is located at the North-East and a kilometer of djilass. It is in the latitude $14^{\circ} 15^{\prime} .552 \mathrm{~N}$ and longitude $16^{\circ} 14^{\prime}$. 495w

Site of Ndoffe-Faoye

Two experimental pieces (herbaceous plot and shrubby plot) were selected in Ndoffe and another (pure plot) in Faoye.

Pure plot

It is located at the south and $2-3 \mathrm{~km}$ of Faoye village. Its geographical coordinates are: $14^{\circ} 11^{\prime} .990 \mathrm{~N}$ and $16^{\circ}$ $35^{\prime} .321 \mathrm{~W}$.

Herbaceous plot 
It is north of Ndoffe and is located at $14^{\circ} 15^{\prime} .466 \mathrm{~N}$ and $16^{\circ} 34^{\prime} .750 \mathrm{~W}$

Shrubby plot

It is also in the North-East of Ndoffe and is located at $14^{\circ} 15^{\prime} .387 \mathrm{~N}$ and $16^{\circ} 34^{\prime} .839 \mathrm{~W}$.

Insert map 2

\subsection{Plots (blocks) characterization}

\subsubsection{Description of the experimental device}

Piezometers are installed in each experimental plot. The results obtained from the sites of study relate to the evolution of the depth, the salinity and the acidity of the water table and the soil.

\subsubsection{Method of water table study}

Pedological drills were used to undertake surveys of water table. The depth of the water table was measured in centimeter; the $\mathrm{pH}$ and the electric conductivity (EC) expressed in millisiemens per centimeter of the water samples collected were measured in the laboratory.

The surveys enabled us to determine water quality and their spatial distribution in the study area.

With the aim of studying the seasonal variations depth, $\mathrm{pH}$ and salinity of the water table, we installed in the center of each experimental piece (plot), a tube piezometer with a diameter 63 millimeters of which the length varies between two meters and four meters. They were installed using a pedological drill 80 millimeters in diameter and 50 centimeters length, were provided with dismountable lengthening-pieces of one meter to two meters length.

In each kind of plots, these piezometers were the subject of a periodic follow-up (five different periods) for the measurement of the water table depth and also taking away water samples in plastic bottles of a quarter liter to double stopper kept with the expenses before analyzing them. Those water samples are analyzed to measure the $\mathrm{pH}$ and the E.C at the analysis laboratory soils - water - plants of the $\mathrm{CNRA}^{2^{*}}$ of Bambey.

Total salinity was estimated from electric conductivity (EC) expressed in $\mathrm{ms} \mathrm{cm}^{-1}$ at $25^{\circ} \mathrm{C}$. Salinity is measured in units of electrical conductivity of water taken from the study area and averaged over time and depth.

The installation of piezometers following a transect in each experimental piece, enabled us to see how the salinity and the acidity of the water table evolve.

2.2.3 Method of soil study

In each experimental piece, a pedological prospection was carried out. Surveys with the pedological drill follow-ups of samplings of soils, were carried out in order to determine the distribution of the soils and their homogeneity. The soil layers (horizons) chosen for the sampling of soil were the following: $0-5 \mathrm{~cm} ; 5-20 \mathrm{~cm}$; $20-40 \mathrm{~cm} ; 90-110 \mathrm{~cm}$ and layer of the water table, on all the experimental pieces.

The taken soil samples are put in plastic sachets numbered before being sent to the analysis laboratory soils water - plants of the CNRA of Bambey.

These samples were dried with the free air, then crushed and filtered with a $2 \mathrm{~mm}$ mesh screen. For each sample, we took 30 grammes of soils, added to $150 \mathrm{ml}$ of distilled water, which correspondsto an extract of soil of 1/5.

On this mixture, the following analyzes were carried out:

- Acidity determined by the $\mathrm{pH}$ of the solution of the water of the ground;

- Salinity determined by the $\mathrm{EC}$ in $\mathrm{ms} \mathrm{cm}^{-1}$ at $25^{\circ} \mathrm{C}$.

\subsection{Tested species behavior study}

\subsubsection{Experimental device}

The adopted experimental method is a factorial with two factors (type of plot and Species). The first factor (type of plot) has three levels (Pure plot, herbaceous plot and shrubby plot) and the second factor (species) has ten levels (A. seyal, A. tortilis, A. nilotica, A. Senegal, A. ampliceps, M. acacioides, M. viriflora, P. juliflora, P. cineraria and C. equisetifolia). The sites (villages) are taken as repetitions. Three plots are considered in Djilass and Ndoff-Faoye. Each kind of species is planted in $625 \mathrm{~m}^{2}$ space and the distance between species is $5 \mathrm{~m} * 5 \mathrm{~m}$. The holes adopted for plantation are $40 \mathrm{~cm} * 40 \mathrm{~cm} * 40 \mathrm{~cm}$. The survival rate, the height and the stem diameter are the measured variables.

\subsubsection{Plant material}

Ten species were tested in our study. They are A.ampliceps, A.nilotica, A.senegal, A.seyal, A.tortilis, C.equisetifolia, P.juliflora, P.cineraria, M.acacioides and M.viridiflora. They were grown in saline and acid sulphated plots. The choices of these species are justified by their characteristics and utilizations. These species seem to be able to fit the ecoclimatic conditions and the local population needs.

2.3.3 Measurements and design

The survival rate, the height and the stem diameter are the measured variables. 


\section{1) Survival rate}

Plant survival rate was quantified in three periods after plantation. A counting from 15 days after plantation was carried out then every week. For this purpose, counting cards were drawn up. We considered three dates reference mark which are 15 days \{rate survival at the time of refilled (RS0)\}, five months (RS1) and eleven months (RS2) after plantation. The species are classified in three categories according to their survival rate. They are qualified very resistant (If survival rate is equal to or higher than 60\%), less resistant (survival rate ranging between 30 and 60\%), sensitive (survival rate ranging between 10 and 30\%) and very sensitive (survival rate understood graft 0 and $10 \%$ ).

2) Growth in height and diameter

Measurements of the height and stem diameter of the seedlings were carried out in three different periods. The material used is composed with a graduated ruler in centimeter and a slide caliper.

3) Collected Data processing

The data collected were analyzed by using Microsoft EXCEL and SPSS 13.0 software. Analyzes of means and Variance have been carried out to detect significant differences at $5 \%$ confidence interval in probability between the treatments for the survival rate, growth in height and diameter.

\section{Results and discussion}

\subsection{Results}

\subsubsection{Sites characterization}

\subsubsection{Salinisation and acidification process}

\section{1) Salinisation}

The salinisation which currently affects these grounds is made by three fundamental processes:

a) Salinisation of the soil by capillary rise (rising water tables)

Salts can be transported to the soil surface by capillary transport from a salt laden water table and then accumulate due to evaporation.

During all the dry season the high temperatures ranging between 25 and $45^{\circ} \mathrm{c}$ which reign in the surface and in the soil cause the evaporation of the soil solution. That involves a concentration in the surface of salts and consequently an increase in salinity. Many work relating to the dynamics of salinity of the soil show that the migration of salts by capillary rise of the soil water and the water table depends on the nature and the concentration of ions. The great mobility of the ion $\mathrm{Cl}^{-}$and $\mathrm{Na}^{+}$would explain the strong concentrations of salts which we notice in the surface of the soils. Thus these migrations constitute the principal process of salinisation of the plots which are not liable to flooding by water of the waterways [Diop, M., 2001].

The accumulation of salts in the profile depends not only on the ascending dynamics of the solution of the soil, but especially also of the EC and depth of the water table.

The downward movements of rainwater involve desalination during the rainy season, but since the installation of the dryness, the migratory flux remains ascending during seven to eight months in the year, causing the salinisation of soils.

\section{b) Salinisation by flood or irrigation}

The salinisation by flood (by the waterways) is the most important process which involves the increase in the salinity of the soils and the water table in the easily flooded plots. This process is rather current and very active. The many ramifications of the hydrographic network and the low altitude of these zones support this process which developed since the installation of the quasi-permanent dryness because of the maintenance of the salinity which is largely higher than the sea salinity during almost all the year [Sadio, S., 1991].

The successive floods result in salt contributions which crystallize under the effect of evaporation on the surface of the soil by forming thick layers (three to five $\mathrm{cm}$ ) with dusty structure of type "carpets" [Marius, C., 1985] that e meet in the plots pure.

The spatial extension of this process depends on the power of the tides and topography on the soil.

The direction of the salinisation flow is currently made of the backwater or valley with the reusable parts in agriculture.

c) Salinisation by transport and accumulation of saline fine particles

The harmattan winds which blow during all the dry season with important speeds exert a strong dynamics on the morphological transformations of the landscape units. Indeed, the saline fine particles torn off of pure plots are transported in the shape of dust and are accumulated in the plots with herbaceous and shrubby vegetation.

The analysis of accumulations reveals that the salinity of a soil is two to three times higher than the subjacent soil [Sadio, S., 1991]. Morphological and granulometric discontinuity between materials brought and the subjacent soil proves that they are indeed salted fine elements transported by the winds 


\section{2) Acidification}

Soil acidification is the buildup of hydrogen cations, also called protons, reducing the soil pH. This happens when a proton donor is added to the soil. The donor can be an acid, such as nitric acid and sulfuric acid. It can also be a compound such as aluminium sulfate, which reacts in the soil to release protons. Acidification also occurs when base cations such as calcium, magnesium, potassium and sodium are lost from the soil. Losses occur when these bases are leached from the soil. This leaching increases with increasing precipitation. Acid rain accelerates the leaching of bases. Acidity takes place when there is transformation of sulfides by oxidation. This oxidation is particularly intense when the moisture of the soil is higher than $10 \%$ [Diop, M., 2001]. The fixing of ions $\mathrm{SO}^{-2}$ by the soil takes really importance only when the soils are blocked up of water. In the presence of water and from oxygen in air in excess, sulphur transforms itself into sulphuric acid according to the reaction:

$$
2 \mathrm{~S}+3 \mathrm{O}_{2}+2 \mathrm{H}_{2} \mathrm{O} \rightarrow 2 \mathrm{H}_{2} \mathrm{SO}_{4}
$$

Thus are explained the two periods during which the soil is suitable to be acidified

[Marius, C., 1985]:

- The first one at the end of the rainy season, during the sulphides oxidation;

- The second period corresponds to the beginning of the rainy season with the hydrolysis of jarosite.

Of this fact, the desiccation of the dry season is opposed to the fall in the soils $\mathrm{pH}$.

In 1988, Sadio showed that acidity in some valleys is also related to the presence of aluminum. Principal constituting minerals and clays, the alumina which is in a free state in the form of oxides and hydroxides in the soils having undergone an intense deterioration is able to degrade clays by the effect of the climate in the tropical soils or by acidification.

In the tropical soils, released alumina takes an inert crystalline form, the gibbsite which, in partnership with iron oxides forms the lateritic armors;

In the very acid soils, the alumina released by degradation of clay, is abundant and contributes to the lowering of the $\mathrm{pH}$.

In acid medium, the exchangeable and soluble alumina excess is toxic for the plant and slows down the absorption of the bivalent cations [Diop, M., 2001]. However above a pH 5.5, there is no more soluble alumina in toxic quantity for the plant.

The abundance of $\mathrm{Fe}^{++}$ions also contributes to maintain the acidity of soils according to the reaction:

$$
\mathrm{Fe}^{++}+2 \mathrm{H}_{2} \mathrm{O} \rightarrow \mathrm{Fe}(\mathrm{OH})_{2}+2 \mathrm{H}^{+}
$$

Thus we understand why the soils which are washed or which suffer from excess water are frequently very acid soils.

3.1.1.2 Plots (blocks) characterization

1) Water table of sites

a) Depth

The depth of the water table varies according to the plot type. The obtained results revealed a great variability of the water table depth in space. We have recorded the depth maximum $-190.04 \mathrm{~cm}$ on the shrubby plot of Djilass and the minimum $-89.5 \mathrm{~cm}$ on the pure plot of Ndoffe. The average depths are respectively $-128 \mathrm{~cm}$ (pure plot of Djilass), - $113 \mathrm{~cm}$ (herbaceous plot of Djilass), - $190.04 \mathrm{~cm}$ (shrubby plot of Djilass), - $89.5 \mathrm{~cm}$ (pure plot of Faoye), $-116 \mathrm{~cm}$ (herbaceous plot of Ndoffe) and $-125.8 \mathrm{~cm}$ (shrubby plot of Ndoffe).

b) $\mathrm{PH}$

The $\mathrm{pH}$ determines the acidity of the water table. It is in general lower or equal to 7 in all the blocks. The herbaceous plot of Djilass recorded values which are very acid (pH lower than 4), just as the shrubby plot.

The $\mathrm{pH}$ is higher in the pure plots (6.23) and (5.17) respectively Djilass and Faoye than the shrubby plots 5.52 (Djilass) and 4.85 (Ndoffe) and the herbaceous plots 3.93 (Djilass) and 3.84 (Ndoffe).

c) EC.

The electric conductivity (EC) is one of the chemical parameters that inform best about the evolution of salinity. It is however very variable on all sites with different values from a piezometer to another. The low values are noted along the transect of the herbaceous plot of Djilass $(\mathrm{EC}<40 \mathrm{mS} / \mathrm{cm})$. This plot located far from the backwater compared to the others is not subject to a great influence of marine water. The lowest value of EC is recorded in the shrubby transect of Djilass; the greatest values are recorded in Faoye (EC. $=181 \mathrm{mS} / \mathrm{cm})$. This situation can be explained by the water table contamination caused by the salted water from the backwater. It is well known that soil conditions, including temperature and moisture, influence EC (McNeill, 1992). Ambient conditions such as air temperature, humidity, and atmospheric electricity can also affect the measurement of EC.

The pure plot of Djilass located downstream from the Diago valley, was subject to the influence of the backwater. But the nature of the soil and topography contribute to a large extent to the fluctuations of the water table. 
We can conclude that more we approach the waterways more the water table becomes salted. This situation can be explained by the effect of the water table contamination by the salted water from the backwater.

Insert table 1

Insert table 2

2) Soils characterization

The process of soil salinisation can be caused by the capillary rise of water table salts particularly during dry season, the training of salts downwards under the action of rainwater or the transport and accumulation of salted fine particles.

Taking into account the great heterogeneity of the medium, we analyzed samples taken from the piezometers according to the following horizons: $0-5 \mathrm{~cm}, 5-20 \mathrm{~cm}$ and the last correspond to the water table.

$\mathrm{EC}$ and $\mathrm{pH}$ values obtained reveal a great spatial variability of salinity and acidity.

a) Soil salinity

There exist less salted soils with an average EC lower than $1 \mathrm{mS} / \mathrm{cm}$. Some are salted in-depth at the water table level with a salinity ranging between 1 and $3 \mathrm{mS} / \mathrm{cm}$, especially noticed on herbaceous and shrubby plots of Djilass and shrubby plot of Ndoffe. Others are salted on the surface (horizon $0-5 \mathrm{~cm}$ ) with a salinity ranging between 2 and $11 \mathrm{mS} / \mathrm{cm}$.

These results show that in the same plot, salinity varies from one horizon to another. The variation of salinity in the soil shows that the distribution of salinity does not follow the depth rule. It is sometimes in decrease, sometimes in increase. Horizon $5-20 \mathrm{~cm}$ is less salted and horizon $0-5 \mathrm{~cm}$ which is more salted.

We have noticed the most salted soils ranging between 2.63 and $14.02 \mathrm{~ms} / \mathrm{cm}$ at Faoye and Ndoffe. At Djilass, the soil salinity is ranging between 1.38 and $5.65 \mathrm{~ms} / \mathrm{cm}$. The pure plot is more salted $(5.65 \mathrm{~ms} / \mathrm{cm})$ than the shrubby plot $(2.81 \mathrm{~ms} / \mathrm{cm})$ and herbaceous plot $(1.38 \mathrm{~ms} / \mathrm{cm})$. That can be caused by the influence of Diago valley.

\section{b) Soil acidity}

The only way to diagnose soil acidity is to test the soil $\mathrm{pH}$. Soil $\mathrm{pH}$ measures the hydrogen ion concentrations (acidity) in the soil solution on a logarithmic scale from $1-14$, with 7 being neutral. The lower soil $\mathrm{pH}$ is greater acid. The profile is globally acid with $\mathrm{pH}$ generally lower than 6.50 . In desiccated medium, as the plots, by oxidation of sulfides under the action of the bacteria like thiooxydans Thiobacillus the released sulphuric acid cause a decrease in the $\mathrm{pH}$ [Marius, C., 1975]. This acidity is the fact of sulfides contained in the soil at the time when the medium was still occupied by marine water and which oxidized out of sulfates during the flood of the soil (case of the plots pure and herbaceous). Thus we have acid sulphated soils.

In a general way, the soil $\mathrm{pH}$ increase with depth .But in this study, we have noticed some exceptions (pure and shrubby plots of Djilass and pure, herbaceous and shrubby plots of Ndoff-Faoye).In these plots, the superficial horizon $(0-5 \mathrm{~cm})$ is more acid than the deep ones. The Lowest average $\mathrm{pH}$ was recorded in Shrubby plot of Djilass $(\mathrm{pH}=4.74)$ and the highest one in the herbaceous of Djilass $(\mathrm{pH}=5.9)$.

These results (soil EC and $\mathrm{pH}$ ) obtained after analyzing samples at the laboratory; reveal that we effectively have saline and acid sulphated soils in our study zone.

Insert table 3

\subsubsection{Survival rate}

Plant salt and acid tolerance or resistance is generally thought of in terms of the inherent ability of the plant to withstand the effects of high salts and acids in the root zone or on the plant's leaves without a significant adverse effect [Shannon, M. C. and C. M. Grieve, 1999]. Of the ten ligneous species tested for salinity and acidity tolerance, seven displayed significant tolerance in the herbaceous and shrubby plots and three (A.ampliceps, C.equisetifolia and P.cineraria) were sensitive. At the pure plots, all the species displayed a sensibility to salinity and acidity. According to our results, species such as M.viridiflora, and M.acacioides, A.senegal and A.nilotica behave well in the herbaceous plot of Djilass. These same species to which are added A.seyal, A.tortilis and P.juliflora also well behaved in the herbaceous plot of Ndoff.

Some species such as A.ampliceps, C.equisetifolia and P.cineraria can't tolerate the plots .The average survival rate of the shrubby plots is more important than the herbaceous plots and the last one is higher than the pure plots. The average survival rate of the species varies within the plot type. The survival of the tested species is more important in shrubby plots than in herbaceous plots. The variability of the survival rate noted between the types of plots is explained by the difference in salinity and acidity. Indeed, the shrubby plots are less salted than those herbaceous which are less salted than the pure plots.

Insert table 4

Insert table 5 


\subsubsection{Growth parameter}

In general, salinity can reduce plant growth or damage the plants through: osmotic effect (causing water deficit), toxic effect of ions and imbalance of the uptake of essential nutrients. These modes of action may operate on the cellular as well as on higher organizational levels and influence all the aspects of plant metabolism [P.J. Kramer, 1983]. The ten species were subjected to saline and acid soils where the $\mathrm{pH}$ is ranging between 4.74 and 5.9 and The EC between 1.38 and $14.02 \mathrm{~ms} / \mathrm{cm}$.

We have observed a growth in height and diameter in all experiment packages. However this growth varies according to the type of plots. M.viridiflora, M.acacioides, A.seyal, A.tortilis A.nilotica and A Senegal displayed a good growth in height in the herbaceous plot of Ndoffe; M.viridiflora, A.nilotica, M.acacioides, A.seyal and A.ampliceps in the shrubby plot of Ndoff; M.viridiflora, M.acacioides, A.nilotica, A.seyal and P.juliflora in the shrubby plot of Djilass; M.viridiflora, A.ampliceps and M.acacioides in the herbaceous plot of Djilass. M.viridiflora and M.acacioides grew well in the shrubby and herbaceous blocks.

A.nilotica and A.seyal experienced their greater development in Diameter in the plots shrubby of Ndoffe and herbaceous of Djilass. P.juliflora, M.acacioides, A.ampliceps, P.cineraria and tortilis have more developed their diameter in the herbaceous plot of Ndoffe than in the other plots. M.viridiflora, A.senegal, A.tortilis and C.equisetifolia found the best conditions for their diameter development in the shrubby plot of Djilass.

No Significant correlations overall were observed between plant relative growth rates and their relative salt and acid tolerances, expressed as percentages.

Insert table 6

Inert table 7

Insert table 8

\subsection{Discussion}

Water of Sine is responsible for the salinity of the water table and the soil and has electric conductivities higher than the sea water [Marius, C., 1985]. Their conductivity varies within the seasons: in rain season, the contributions of fresh water decrease salinity whereas in dry season, the salinity increases.

We notice important seasonal variations on the water table. In rainy season, it goes up. The dilution of the water table by rainwater involves the electric conductivity fall which remains always very high compared to the normal $(2 \mathrm{~ms} / \mathrm{cm})$ hoping to obtain a good output after plantation. In dry season, the water table drops and water becomes more mineral-bearing involving an increase in electric conductivity.

We also notice the same seasonal variations as the water table on the soils. Maximum soil salinity is found during the dry period and minimum during the rainy season (wet period) in the year. The soil profile is salted at the horizon of the water table and very salted on the surface.

The behavior of the species according to the morphopedologic units is explained by the fact of the difference of salinity and acidity between the plots. Species behave according to the medium and their tolerance to salinity and acidity. Each kind of species has a threshold of tolerance to salinity and acidity. The species which behaved well can be used for the economic development of these types of soils. However we note the good behavior of some species as M.viriflora, M.acacioides, A.seyal, A.tortilis, A.nilotica, A.senegal and P.juliflora in the shrubby and herbaceous blocks.

\section{Conclusion}

Afforestation of saline and acid sulphated soils requires that special attention is paid to species choices and management level. It is somewhat difficult to grow plants in pure plots, the stress that the trees face depends on the soils salinity and acidity and the quality of groundwater along with its depth. It is essential to understand these stresses in order for a successful plantation on saline and acid sulphated soils .Although this study displayed that some species (7) are very tolerant to salinity and acidity conditions and three species are very sensitive. The plant survival rate, growth in height and diameter displayed significant differences between the treatments and the repetitions. C.equisetifolia, A.ampliceps and P.cineraria tested sensitivity in all the types of plots. In the herbaceous plot of Djilass, the species (M. viridiflora, M.acacioides, A.senegal and A.nilotica) had a good survival rate; whereas at Ndoffe, it is A.nilotica, A.seyal, M.acacioides, A.tortilis and P.juliflora. In the shrubby plots, it is M.acacioides, A.senegal, A.seyal, A.tortilis, A.nilotica, P.juliflora, and M.viridiflora for Djilass and A.tortilis, A.nilotica, M.acacioides, P.juliflora, A.seyal, M.viridiflora and A.senegal for Ndoffe. All the species are sensitive to the plots pure.

The combined results of survival rate, growth in height and in diameter indicated us the possibilities to develop and re combined store the herbaceous and shrubby plots by the some woody species such as A.nilotica, A. Senegal, A.seyal, A.tortilis, M.acacioide, M.viridiflora and P.juliflora.

\section{References}

Akhtar, J., S.Ahmad and A.M. Kauser. (2002). Use of brakish-water for agriculture: Growth of salt-tolerant plants and their effects on soil-properties, Sci. Version, 7: 230-241 
Diop, M. (2001). Analyzes proposals for an agronomic valorization of the salted grounds: case of the PRASS II ${ }^{3 *}$ and the PAGERNA ${ }^{4^{*}}$. Memory of end of studies, ENCR ${ }^{5^{*}}$., Bambey. 69pages. (in French)

Marius, C. (1985). Mangroves of Senegal and Gambia: Ecology-Pedology-geochemistry: Installation and development. ORSTOM ${ }^{6^{*}}$, Dakar. 368pages.(in French)

Marius, C. (1975). Chronological Evolution of the estuary soils of Saloum (Senegal). Edition-ORSTOM, Dakar. 76pages. (in French)

Massibot, J.A. and Carles L. (1946). Development of the rizicultivable plots of Sine (Senegal) - extract 10 pages (in French)

McNeill, J.D. (1992). Rapid, accurate mapping of soil salinity by electromagnetic ground conductivity meters. In: Advances in Measurement of Soil Physical Properties: Bringing Theory Into Practice. Spec. Publ. 30, SSSA, Madison, WI, pp. 209-229.

Ndour B. And Sarr A. (1994). Evaluation of the agroforestries potentialities of the salted grounds of Sine-Saloum (memory of Master in Sciences of the Environment, UCAD ${ }^{7^{*}}$ ) 79 pages (in French)

P.J. Kramer. (1983). Water Relations of Plants, Academic Press, New York.

Rhoades, J.D. and Loveday, J. (1990). Salinity inirrigated agriculture. In American Society of Civil Engineers, Irrigation of Agricultural Crops (Monograph 30) (Steward, B.A. and Nielsen, D.R., eds), pp. 1089-1142, American Society of Agronomists

Rhoades, J.D, Chanduvi, F., Lesch, S.M. (1999). Soil Salinity Assessment: Methods and Interpretation of Electrical Conductivity Measurements. FAO Irrigation and Drainage Paper 57. Food and Agricultural Organization of the United Nations, Rome, Italy

Sadio, S. (1991). Pedogenesis and forest potentialities of the sulphated soils of Sine Saloum (Senegal). Doctorate, éd. ORSTOM, Dakar. 269pages.(in French)

Sadio, S. (1986). Pedological study of the factors of mortality of the forest gasolines introduced in mediums salted in Senegal: Afforestation of Niayes and Sine Saloum. 67pages. (in French)

Shadded, M.A., Zidan, M.A. (1989). Effect of $\mathrm{NaCl}$ salinity on the rate of germination, seedling growth, and some metabolic changes in Raphanus sativum L. and Trigonella foenum-graecum L. Beitr. Trop. Landwirtsch. Vet. Med. 27, 187 \pm 194 .

Shannon, M. C. and C. M. Grieve. (1999). Tolerance of vegetable crops to salinity. Scientia hortic., $78: 5-38$.

Uno, Y., Kanechi, M., Inagaki, N., Sugimoto, M., Maekawa, S. (1996). The evaluation of salt tolerance during germination and vegetative growth of asparagus, table beet and sea aster. J. Jpn. Soc. Hort. Sci. 65, $579 \pm 585$.

Y. SHIROKOVA, I. FORKUTSA \& N. SHARAFUTDINOVA. (2000). Use of electrical conductivity instead of soluble salts for soil salinity monitoring in Central Asia. Central Asian Research Institute of Irrigation, SANIIRI, N, 11 Karasu-4 District, Tashkent 700187, Uzbekistan.

*Notes:

Note 1. Global Positioning System

Note 2. Centre National de Recherche Agronomique

Note 3. Projet de restauration Agronomique des Sols Salés

Note 4. Projet d'Autopromotion et de Gestion des Ressources Naturelles au Sine Saloum.

Note 5. Ecole Nationale des Cadres Ruraux.

Note 6. Office de Recherche Scientifique et Technique d'Outre - Mer.

Note 7. Université Cheikh Anta Diop 
Table 1 . The water table $\mathrm{pH}$ and $\mathrm{EC}(\mathrm{mS} / \mathrm{cm})$

\begin{tabular}{|c|c|c|c|c|}
\hline localtion & transect on plot & samples & $\mathrm{pH}$ & $\mathrm{EC}$ \\
\hline Djilass & 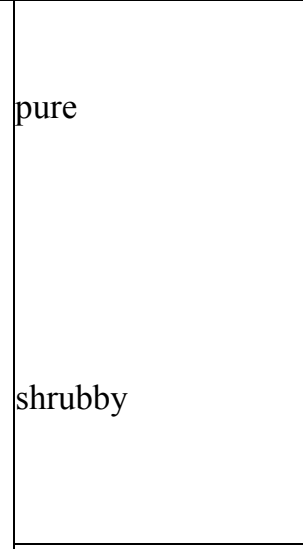 & $\begin{array}{l}\mathrm{P} 1.2 \\
\mathrm{P} 1.4 \\
\mathrm{P} 1.5 \\
\mathrm{P} 1.6 \\
\mathrm{P} 1.7 \\
\mathrm{P} 2.1 \\
\mathrm{P} 2.2 \\
\mathrm{P} 2.3 \\
\mathrm{P} 2.4 \\
\mathrm{P} 2.5 \\
\mathrm{P} 2.7\end{array}$ & $\begin{array}{l}6,15 \\
4,22 \\
4,93 \\
5,9 \\
5,55 \\
3,86 \\
6,7 \\
3,7 \\
4,86 \\
7,16 \\
3,88\end{array}$ & $\begin{array}{l}80,98 \\
47,14 \\
71,31 \\
105,15 \\
55,11 \\
23,57 \\
10,76 \\
39,28 \\
47,14 \\
60,43 \\
29,37\end{array}$ \\
\hline & herbaceous & $\begin{array}{l}\text { P3.1 } \\
\text { P3.2 } \\
\text { P3.3 } \\
\text { P3.4 } \\
\text { P3.5 } \\
\text { P3.6 } \\
\text { P3.7 }\end{array}$ & $\begin{array}{l}7,24 \\
7,05 \\
3,21 \\
3,58 \\
3,15 \\
7,35 \\
7,23 \\
\end{array}$ & $\begin{array}{l}36,26 \\
11,96 \\
37,47 \\
145,04 \\
23,57 \\
25,74 \\
32,99\end{array}$ \\
\hline & \begin{tabular}{|l} 
herbaceous \\
shrubby
\end{tabular} & $\begin{array}{l}\text { P.H } \\
\text { P.S }\end{array}$ & $\begin{array}{l}2,82 \\
6,49\end{array}$ & $\begin{array}{l}106,97 \\
49,86\end{array}$ \\
\hline Ndoffe & $\begin{array}{l}\text { Between herbaceous } \\
\text { and shrubby }\end{array}$ & $\begin{array}{l}\text { P4.1 } \\
\text { P4.2 } \\
\text { P4.3 } \\
\text { P4.4 } \\
\text { P4.5 } \\
\text { P4.6 }\end{array}$ & $\begin{array}{l}6,49 \\
4,42 \\
5,95 \\
4,81 \\
4,68 \\
6,37\end{array}$ & $\begin{array}{l}19,94 \\
79,77 \\
110,59 \\
\\
29,37 \\
111,2 \\
149,88\end{array}$ \\
\hline Faoye & pure & $\begin{array}{l}\text { P5.3 } \\
\text { P5.4 } \\
\text { P5.5 }\end{array}$ & $\begin{array}{l}4,17 \\
5,23 \\
5,68\end{array}$ & $\begin{array}{l}88,23 \\
172,29 \\
181,3\end{array}$ \\
\hline
\end{tabular}

$\mathrm{P} 1.2=(\mathrm{P}=$ piezometer, $1=$ Piezometer number 1 and $2=$ sample number 2$)$

$\mathrm{P} . \mathrm{H}=$ Piezometer in Herbaceous plot

P.S = Piezometer in Shrubby plot 
Table 2. The water table depth $(\mathrm{cm}), \mathrm{pH}$ and EC $(\mathrm{mS} / \mathrm{cm})$ Measurements according to time

\begin{tabular}{|c|c|c|c|c|c|c|c|c|c|c|c|c|c|c|c|c|c|c|}
\hline \multirow{3}{*}{ Periods } & \multicolumn{9}{|c|}{ Site Of Djilass } & \multicolumn{9}{|c|}{ Site of Ndoffe - Faoye } \\
\hline & \multicolumn{3}{|c|}{ Pure plot } & \multicolumn{6}{|c|}{ Herbaceous plotShrubby plot } & \multicolumn{3}{|c|}{ Pure plot } & \multicolumn{6}{|c|}{ Herbaceous plotShrubby plot } \\
\hline & Deptl & $\mathrm{pH}$ & $\mathrm{EC}$ & Depth & $\mathrm{pH}$ & $\mathrm{EC}$ & Depth & $\mathrm{h} \mathrm{pH}$ & $\mathrm{EC}$ & Depth & $\mathrm{pH}$ & $\mathrm{EC}$ & Depth & $\mathrm{pH}$ & $\mathrm{EC}$ & Depth & $\mathrm{pH}$ & $\mathrm{EC}$ \\
\hline 01 & -133 & 5,31 & 168,3 & $4-61$ & 4,99 & 94,28 & -173 & 4,2 & 430,6 & $9-64$ & 4,51 & 1143,63 & -81 & 4,29 & 976,5 & -101 & 3,9 & 41,7 \\
\hline 02 & -80 & 5,99 & 970,6 & 5-90 & 4,33 & 34,05 & -164 & 5,8 & 232,4 & $3-55$ & 4,4 & 150,58 & -83 & 4,06 & 655,6 & -76 & 3,25 & 544,59 \\
\hline 03 & -108 & 7,48 & 876,26 & $6-118$ & 3,73 & 317,05 & -181 & 6,03 & 335,3 & $4-93$ & 6,55 & 5158,72 & -106 & - & - & -147 & 3,77 & 748,36 \\
\hline 04 & -154 & - & - & -147 & 3,41 & 129,61 & -202 & 4,84 & 438,0 & 7-111 & - & - & -153 & 4,2 & 87 & -150 & 6,86 & 661,64 \\
\hline 05 & -165 & 6,15 & 580,98 & $8-149$ & 3,21 & 137,47 & -232 & 6,7 & 10,7 & $5-124,5$ & 5,23 & $\begin{array}{lll}3 & 172,29\end{array}$ & -159 & 2,82 & 2107 & -155 & 6,49 & 949,86 \\
\hline average & -128 & 6.23 & 374.0 & $5-113$ & 3.93 & 318.49 & -190.4 & 5.52 & 229.4 & $5-89.5$ & 5.17 & 7156.3 & -116.4 & 3.84 & 481.52 & -125.8 & & 549.23 \\
\hline
\end{tabular}

Table 3. The soil solution $\mathrm{PH}$ and the EC $(\mathrm{mS} / \mathrm{cm})$

\begin{tabular}{|c|c|c|c|c|}
\hline Sites & Plots (blocks) & Horizon $(\mathrm{cm})$ & $\mathrm{EC}$ & $\mathrm{pH}$ \\
\hline \multirow[t]{9}{*}{ Djilass } & \multirow[t]{3}{*}{ pure } & $0-5$ & 9.99 & 6.04 \\
\hline & & $5-20$ & 2.44 & 5.44 \\
\hline & & $170-310$ & 4.54 & 4.48 \\
\hline & \multirow[t]{3}{*}{ Herbaceous } & $0-5$ & 1.99 & 5.56 \\
\hline & & $5-20$ & 0.51 & 5.35 \\
\hline & & $185-235$ & 1.65 & 6.79 \\
\hline & \multirow[t]{3}{*}{ Shrubby } & $0-5$ & 4.641 & 5.27 \\
\hline & & $5-20$ & 0.59 & 5.34 \\
\hline & & $120-240$ & 3.2 & 3.62 \\
\hline \multirow[t]{9}{*}{ Ndoffe-Faoye } & \multirow[t]{3}{*}{ Pure } & $0-5$ & 22.78 & 6.485 \\
\hline & & $5-20$ & 9.27 & 5.88 \\
\hline & & $90-146$ & 10.017 & 4.73 \\
\hline & \multirow[t]{3}{*}{ Herbaceous } & $0-5$ & 24.47 & 5.94 \\
\hline & & $5-20$ & 6.10 & 5.35 \\
\hline & & $185-235$ & 7.91 & 3.82 \\
\hline & \multirow[t]{3}{*}{ Shrubby } & $0-5$ & 3.75 & 6.05 \\
\hline & & $5-20$ & 1.27 & 5.38 \\
\hline & & $120-240$ & 2.87 & 4.03 \\
\hline
\end{tabular}


Table 4. Species classification according to their salinity and acidity tolerance

\begin{tabular}{|c|c|c|c|c|}
\hline Plot type & $\begin{array}{l}\text { Very resistant } \\
\text { species }\end{array}$ & $\begin{array}{l}\text { Less resistant } \\
\text { species }\end{array}$ & $\begin{array}{l}\text { Sensitive } \\
\text { species }\end{array}$ & Very sensitive species \\
\hline $\begin{array}{l}\text { Pure plot } \\
\text { of Djilass }\end{array}$ & - & - & - & $\begin{array}{l}\text { A.seyal,A..tortilis, A.nilotica, } \\
\text { A.Senegal,A.ampliceps, M.acacioides, } M \text {. } \\
\text { viriflora, P. juliflora,P. cineraria and } C \text {. } \\
\text { equisetifolia }\end{array}$ \\
\hline $\begin{array}{l}\text { Pure Plot } \\
\text { of Faoye }\end{array}$ & - & - & - & $\begin{array}{l}\text { A.seyal,A..tortilis, A.nilotica, } \\
\text { A.Senegal,A.ampliceps, M.acacioides, } M \text {. } \\
\text { viriflora, P. juliflora,P. cineraria and } C \text {. } \\
\text { equisetifolia }\end{array}$ \\
\hline $\begin{array}{l}\text { Herbaceous } \\
\text { plot of } \\
\text { Djilass }\end{array}$ & $\begin{array}{l}\text { M.viridiflora } \\
(76 \%) \text { and } \\
\text { M.acacioides } \\
(72 \%)\end{array}$ & $\begin{array}{l}\text { A.senegal } \\
(56 \%) \text { and } \\
\text { A.nilotica } \\
(52 \%)\end{array}$ & $\begin{array}{l}\text { P.juliflora } \\
(24 \%) \text { and } \\
\text { A.tortilis } \\
(20 \%) \\
\end{array}$ & $\begin{array}{l}\text { A.ampliceps, P.cinerariaet A.seyal (4\%) } \\
\text { and C.equisetifolia }(0 \%) \text {. }\end{array}$ \\
\hline $\begin{array}{l}\text { Herbaceous } \\
\text { plot of } \\
\text { Ndoff }\end{array}$ & $\begin{array}{l}\text { A.nilotica } \quad(76 \%) \\
\text { and A.seyal }(60 \%)\end{array}$ & $\begin{array}{l}\text { M.acacioides } \\
(56 \%) \text {,A.tortilis } \\
(32 \%) \text { and } \\
\text { P.juliflora } \\
(48 \%)\end{array}$ & $\begin{array}{l}\text { A.senegal } \\
(20 \%)\end{array}$ & $\begin{array}{l}\text { A.ampliceps and M.viridiflora (8\%), } \\
\text { P.cineraria and C.equisetifolia }(0 \%) \text {. }\end{array}$ \\
\hline \multirow[t]{2}{*}{$\begin{array}{l}\text { Shrubby } \\
\text { plot of } \\
\text { Djilass }\end{array}$} & $\begin{array}{l}\text { M.acacioides } \\
(92 \%), \\
\text { A.seyal }(76 \%), \\
\text { A.tortilis }(72 \%), \\
\text { A.senegal }(64 \%), \\
\text { A.nilotica and } \\
\text { P.juliflora }(60 \%)\end{array}$ & $\begin{array}{l}\text { M.viridiflora } \\
(40 \%)\end{array}$ & $\begin{array}{l}\text { P.juliflora } \\
(24 \%) \text { and } \\
\text { A.tortilis } \\
(20 \%)\end{array}$ & $\begin{array}{l}\text { A.ampliceps, P.cinerariaet A.seyal (4\%) } \\
\text { and C.equisetifolia }(0 \%) \text {. }\end{array}$ \\
\hline & $\begin{array}{l}\text { A.nilotica }(100 \%), \\
\text { A.tortilis, } \\
\text { M.acacioides and } \\
\text { P.juliflora }(96 \%) \text {, } \\
\text { A.seyal }(92 \%, \\
\text { M.viridiflora }(76 \%) \text {, } \\
\text { A.senegal and } \\
\text { P.cineraria }(68 \%)\end{array}$ & - & $\begin{array}{l}\text { A.ampliceps } \\
\text { and } \\
\text { C.equisetifolia } \\
(24 \%)\end{array}$ & - \\
\hline
\end{tabular}

Table 5. Survival rate $(\%)$ results of species

\begin{tabular}{|c|c|c|c|c|c|c|c|c|c|c|c|c|c|c|c|c|c|c|}
\hline \multirow[t]{2}{*}{ Species } & \multicolumn{3}{|l|}{$\mathrm{PpF}$} & \multicolumn{3}{|l|}{$\mathrm{PpD}$} & \multicolumn{3}{|l|}{ PHD } & \multicolumn{3}{|l|}{ PHN } & \multicolumn{3}{|l|}{ PSD } & \multicolumn{3}{|l|}{ PSN } \\
\hline & RS0 & RS1 & RS2 & RS0 & RS1 & $\mathrm{RS} 2$ & RS0 & RS1 & RS2 & RS0 & RS1 & RS2 & RS0 & RS1 & RS2 & RS0 & RS1 & RS2 \\
\hline A.senegall & 0 & 0 & 0 & 4 & 4 & 0 & 92 & 68 & 56 & 20 & 28 & 20 & 92 & 100 & 64 & 76 & 76 & 68 \\
\hline A.nilotica & 0 & 0 & 0 & 16 & 20 & 0 & 100 & 100 & 52 & 60 & 84 & 76 & 100 & 96 & 60 & 100 & 100 & 100 \\
\hline A.tortilis & 0 & 0 & 0 & 8 & 16 & 0 & 92 & 32 & 20 & 68 & 48 & 32 & 96 & 96 & 72 & 100 & 100 & 96 \\
\hline A,seyal & 0 & 0 & 0 & 28 & 12 & 0 & 88 & 48 & 4 & 52 & 68 & 60 & 100 & 100 & 76 & 100 & 100 & 92 \\
\hline A.ampliceps & 0 & 0 & 0 & 0 & 0 & 0 & 20 & 28 & 4 & 20 & 12 & 8 & 100 & 60 & 0 & 68 & 60 & 24 \\
\hline M.acacioides & 0 & 0 & 0 & 0 & 12 & 0 & 88 & 76 & 72 & 52 & 60 & 56 & 100 & 100 & 92 & 100 & 100 & 96 \\
\hline M.viridiflora & 0 & 0 & 0 & 0 & 0 & 0 & 88 & 88 & 76 & 40 & 28 & 8 & 92 & 68 & 40 & 80 & 68 & 76 \\
\hline P.juliflora & 0 & 0 & 0 & 0 & 32 & 0 & 100 & 96 & 24 & 64 & 60 & 48 & 100 & 92 & 60 & 100 & 100 & 96 \\
\hline P.cineraria & 0 & 0 & 0 & 0 & 0 & 0 & 80 & 60 & 4 & 36 & 16 & 4 & 88 & 96 & 36 & 76 & 88 & 68 \\
\hline C.equisetifolia & 0 & 0 & 0 & 0 & 0 & 0 & 100 & 88 & 0 & 60 & 72 & 0 & 92 & 56 & 0 & 96 & 76 & 24 \\
\hline average & 0.0 & 0.0 & 0.0 & 5.6 & 9.6 & 0.0 & 84.8 & 68 & 31.2 & 47.2 & 47.6 & 31.2 & 96 & 86 & 50 & 89.6 & 86.8 & 74 \\
\hline
\end{tabular}

$\mathrm{P}=$ plot; $\mathrm{p}=$ pure; $\mathrm{D}=$ Djilass; $\mathrm{H}=$ herbaceous; $\mathrm{S}=$ shrubby; $\mathrm{N}=\mathrm{Ndoffe} ; \mathrm{F}=$ Faoye 
Table 6. Plant Height $(\mathrm{cm})$ measurement results

\begin{tabular}{|c|c|c|c|c|c|c|c|c|c|c|c|c|c|c|c|c|c|c|}
\hline \multirow[t]{2}{*}{ species } & \multicolumn{3}{|l|}{$\mathrm{PpF}$} & \multicolumn{3}{|l|}{$\mathrm{PpD}$} & \multicolumn{3}{|c|}{ PHD } & \multicolumn{3}{|l|}{ PHN } & \multicolumn{3}{|l|}{ TSD } & \multicolumn{3}{|l|}{ PSN } \\
\hline & $\mathrm{HO}$ & $\mathrm{H} 1$ & $\mathrm{H} 2$ & $\mathrm{H} 0$ & H1 & $\mathrm{H} 2$ & $\mathrm{H} 0$ & H1 & $\mathrm{H} 2$ & $\mathrm{HO}$ & $\mathrm{H} 1$ & $\mathrm{H} 2$ & $\mathrm{H} 0$ & H1 & $\mathrm{H} 2$ & $\mathrm{H} 0$ & H1 & $\mathrm{H} 2$ \\
\hline A.seyal & 44.4 & & & 44.4 & & & 44.4 & 45 & 46.1 & 44.4 & 56 & 65 & 44.4 & 48 & 51.7 & 44.4 & 47.8 & 53 \\
\hline A.tortilis & 47.4 & & & 47.4 & & & 47.4 & 48.2 & 50.4 & 47.4 & 51 & 58 & 47.4 & 49 & 51 & 47.4 & 47.6 & 48 \\
\hline A.nilotica & 43 & 43.5 & & 43 & & & 43 & 45 & 47 & 43 & 47.3 & 49.9 & 43 & 45 & 51 & 43 & 52.8 & 60.4 \\
\hline M.viridiflora & 14.5 & & & 14.5 & & & 14.5 & 37.6 & 49.6 & 14.5 & 57.3 & 70 & 14.5 & 62.6 & 71 & 14.5 & 65.4 & 74.7 \\
\hline P.juliflora & 60.3 & 60.7 & & 60.3 & & & 60.3 & 61.8 & 63.2 & 60.3 & 64.4 & 65 & 60.3 & 63.6 & 65.6 & 60.3 & 60.8 & 61 \\
\hline P.cineraria & 29 & & & 29 & & & 29 & 29.8 & 31.5 & 29 & 29.5 & 30 & 29 & 29.4 & 29.8 & 29 & 30 & 30.5 \\
\hline C.equisetifolia & 30.5 & & & 30.5 & & & 30.5 & 32 & & 30.5 & 32 & & 30.5 & 31.1 & & 30.5 & 32 & 33.6 \\
\hline average & 34.6 & & & 34.6 & & & 34.6 & 38.7 & 42.3 & 34.6 & 45.23 & 50.64 & 34.6 & 42.69 & 49.625 & 34.6 & 42.83 & 46.19 \\
\hline
\end{tabular}

$\mathrm{H} 0=$ height of plant in nursery; $\mathrm{H} 1=$ height of plant during the first measurement; $\mathrm{H} 2=$ height of plant during the second measurement

$\mathrm{P}=$ plot $; \mathrm{p}=$ pure $; \mathrm{D}=$ Djilass, $\mathrm{H}=$ herbaceous; $\mathrm{S}=$ shrubby; $\mathrm{N}=\mathrm{Ndoffe} ; \mathrm{F}=$ Faoye

Table 7. Stem Diameter $(\mathrm{cm})$ measurement results

\begin{tabular}{|l|l|l|l|l|l|l|l|l|l|l|l|l|}
\hline species & PpF & PpD & \multicolumn{2}{l|}{ PHD } & \multicolumn{2}{l|}{ PHN } & PSD & PSN \\
\hline & D1 & D2 & D1 & D2 & D1 & D2 & D1 & D2 & D1 & D2 & D1 & D2 \\
\hline A.seyal & & & & & 0.49 & 0.9 & 0.69 & 0.87 & 0.53 & 0.59 & 0.65 & 0.7 \\
\hline A.senegal & & & & & 0.58 & 0.6 & 0.51 & 0.6 & 0.62 & 0.71 & 0.65 & 0.7 \\
\hline A.tortilis & & & & & 0.56 & 0.6 & 0.6 & 0.6 & 0.53 & 0.6 & 0.6 & 0.6 \\
\hline A.nilotica & & & 0.8 & & 1.05 & 1.5 & 1 & 1.1 & 0.95 & 1 & 1.5 & 1.6 \\
\hline A.ampliceps & & & & & 0.56 & 0.7 & 0.73 & 0.9 & 0.49 & & 0.5 & 0.6 \\
\hline M.acacioides & & & & & 0.53 & 0.67 & 0.77 & 1.09 & 0.7 & 0.87 & 0.55 & 0.7 \\
\hline M.viridiflora & & & & & 0.91 & 1 & 0.8 & 1 & 0.58 & 1.27 & 0.85 & 1.1 \\
\hline P.juliflora & & & 0.7 & & 0.7 & 0.9 & 1 & 1.1 & 0.74 & 0.8 & 0.8 & 0.8 \\
\hline P.cineraria & & & & & 0.44 & 0.7 & 0.55 & 0.8 & 0.4 & 0.46 & 0.48 & 0.5 \\
\hline C.equisetifolia & & & & & 0.4 & & 0.5 & & 0.4 & & 0.5 & 0.6 \\
\hline average & & & 0.75 & & 0.62 & 0.84 & 0.72 & 0.9 & 0.62 & 0.788 & 0.71 & 0.8 \\
\hline
\end{tabular}

$\mathrm{D} 1=$ diameter during the first measurement; $\mathrm{D} 2=$ =iameter during the second measurement

Table 8. results recapitulation

\begin{tabular}{|c|c|c|c|c|c|c|c|}
\hline \multicolumn{7}{|c|}{ Characterization } & \multirow[t]{3}{*}{ Tolerant species } \\
\hline & & \multicolumn{3}{|c|}{ Water table } & \multicolumn{2}{|l|}{ Soil } & \\
\hline Sites & Plots(blocks) & $\begin{array}{l}\text { Depth( } \\
\text { Cm) }\end{array}$ & $\mathrm{pH}$ & $\begin{array}{l}\mathrm{EC}(\mathrm{m} \\
\mathrm{S} / \mathrm{Cm})\end{array}$ & $\mathrm{pH}$ & $\begin{array}{l}\mathrm{EC}(\mathrm{mS} \\
/ \mathrm{Cm})\end{array}$ & \\
\hline \multirow[t]{3}{*}{ Djilass } & Pure & -128 & 6.23 & 74.05 & $\begin{array}{l}5.3 \\
2\end{array}$ & 5.65 & - \\
\hline & Herbaceous & -113 & 3.93 & 18.49 & 5.9 & 1.38 & $\begin{array}{l}\text { M.viridiflora,M.acacioides,A.senegal } \\
\text { and A.nilotica }\end{array}$ \\
\hline & Shrubby & -190.4 & 5.52 & 29.45 & $\begin{array}{l}4.7 \\
4\end{array}$ & 2.81 & $\begin{array}{l}\text { M.acacioides,A.seyal,A.tortilis,A.sene } \\
\text { gal,A.nilotica,P.juliflora and } \\
\text { M.viridiflora }\end{array}$ \\
\hline \multirow[t]{3}{*}{$\begin{array}{l}\text { Ndoffe } \\
\text {-Faoye }\end{array}$} & Pure & -89.5 & 5.17 & 156.3 & $\begin{array}{l}5.6 \\
9\end{array}$ & 14.02 & - \\
\hline & Herbaceous & -116.4 & 3.84 & 81.52 & $\begin{array}{l}5.0 \\
3 \\
\end{array}$ & 12.83 & $\begin{array}{l}\text { A.nilotica,A.seyal,M.acacioides,A.torti } \\
\text { lis and P.juliflora }\end{array}$ \\
\hline & Shrubby & -125.8 & 4.85 & 49.23 & $\begin{array}{l}5.1 \\
5\end{array}$ & 2.63 & $\begin{array}{l}\text { A.nilotica,A.tortilis,M.acacioides,P.jul } \\
\text { iflora,A.seyal,M.viridiflora and } \\
\text { A.senegal }\end{array}$ \\
\hline
\end{tabular}




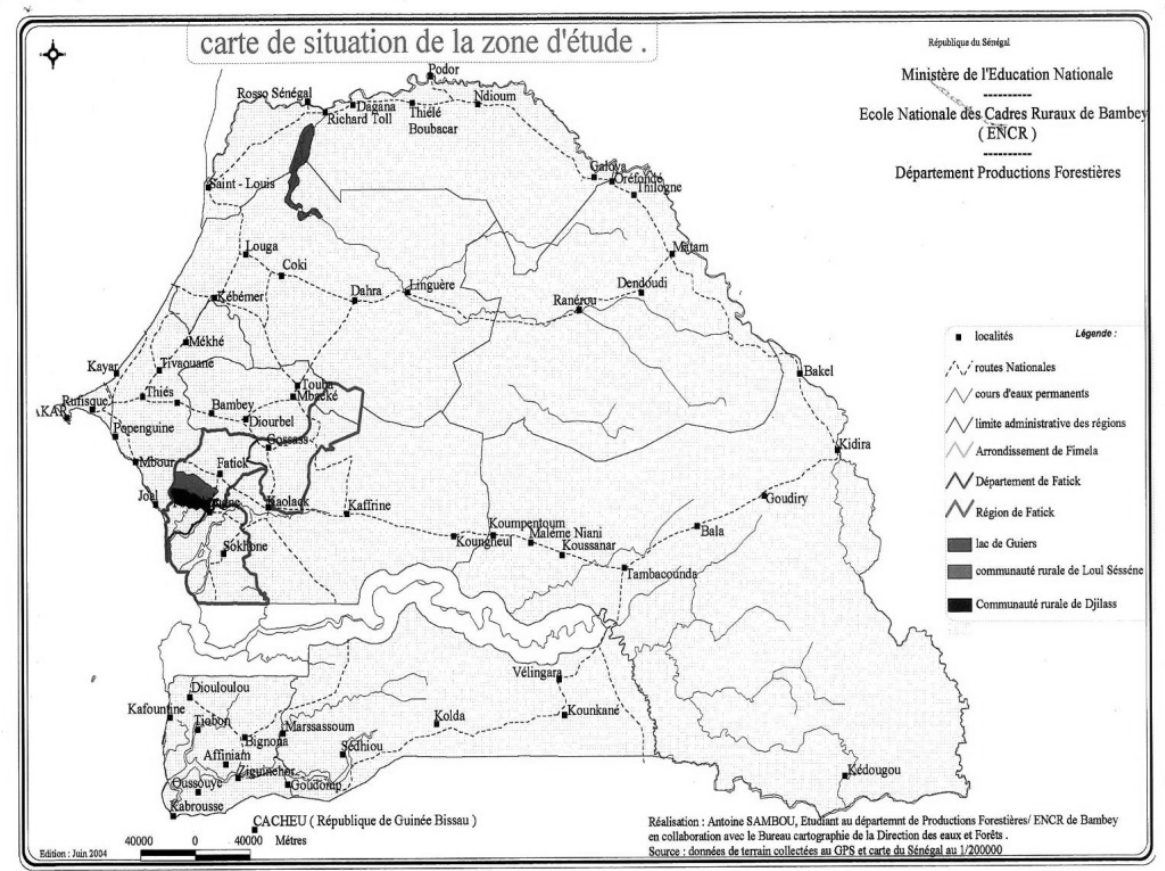

Map 1. Study area location

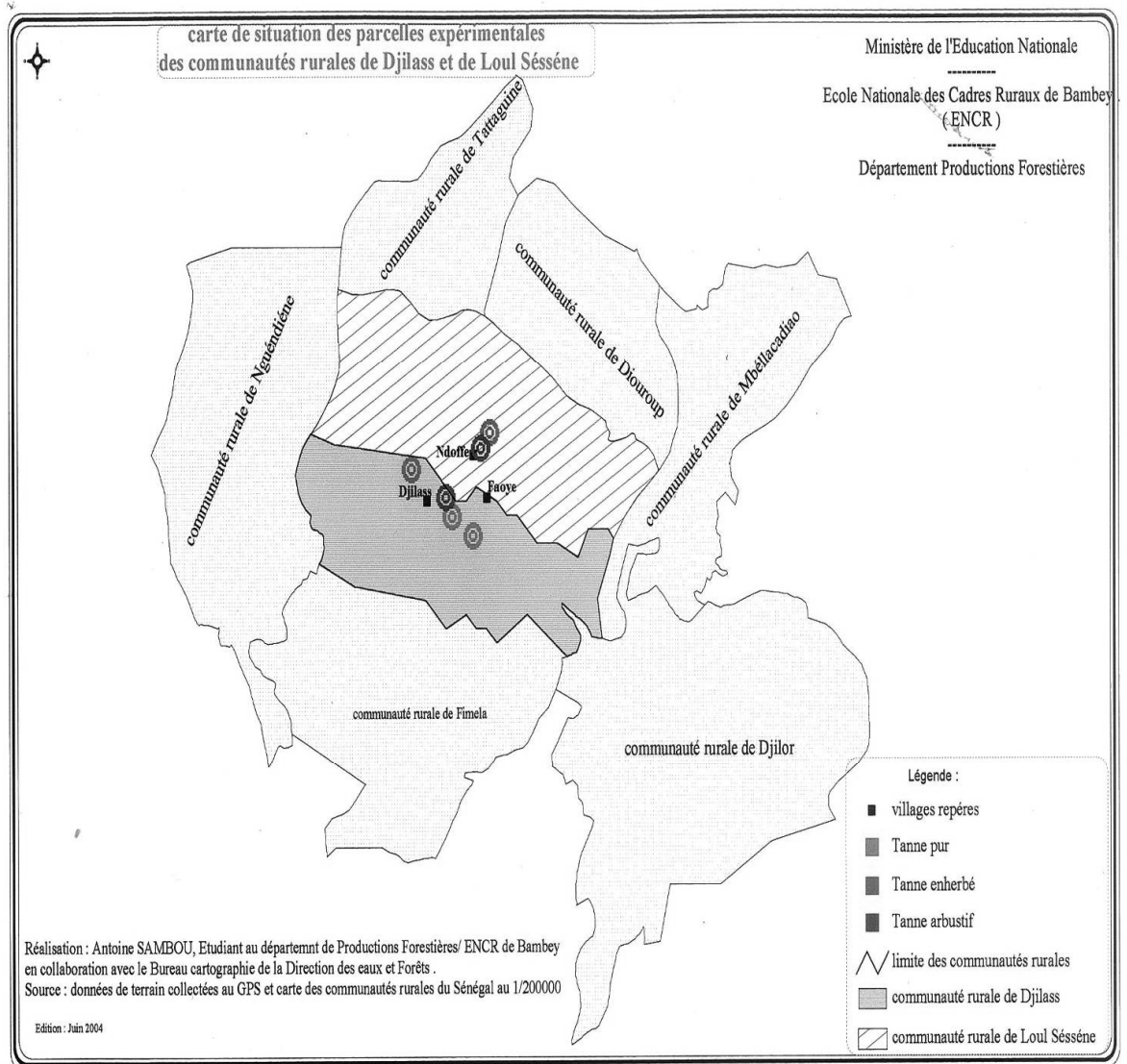

Map 2. Experimental pieces location 